Etikonomi

Volume 15 (2), October 2016

P-ISSN: 1412-8969; E-ISSN: 2461-0771

Page 125 - 138

\title{
THE EFFECT OF ASEAN-CHINA FREE TRADE AREA (ACFTA) ON INDONESIA EXPORT
}

\author{
Indriyani \\ Universitas Indonesia \\ beautifulrain_indri@yahoo.co.id
}

\begin{abstract}
.
ASEAN-China Free Trade Area (ACFTA) is an agreement between the members of ASEAN and China to create a free trade area by removing tariff and non-tariff barriers. This agreement begins with the signing of the agreement on November 5, 2002 in Phnom Penh. Implementation is done in phases beginning January 1, 2004. The purpose of this study determines the effect of the implementation of ACFTA on Indonesia's exports to the ASEAN countries and China. This study complements previous research regarding the ACFTA. The data used in this study are the data of Indonesian exports to ASEAN countries and China for 15 years from 2000 until 2014. The tests were conducted with a fixed effect panel data model with cross section SUR. The results of this study indicate that the ACFTA increase Indonesian exports to the ASEAN countries and China.
\end{abstract}

Keywords: ACFTA; export; trade liberalization

\begin{abstract}
Abstrak.
ASEAN-China Free Trade Area (ACFTA) merupakan kesepakatan antara negara-negara anggota ASEAN dengan China untuk mewujudkan kawasan perdagangan bebas dengan menghilangkan hambatan tarif dan non tarif. Kesepakatan ini diawali dengan penandatanganan perjanjian pada tanggal 5 November 2002 di Phnom Penh. Pelaksanaannya dilakukan secara bertahap dimulai 1 Januari 2004. Tujuan dari penelitian ini adalah mengetahui pengaruh penerapan ACFTA terhadap ekspor Indonesia ke negaranegara ASEAN dan China. Penelitian ini melengkapi penelitian sebelumnya mengenai ACFTA. Data yang digunakan dalam penelitian ini adalah data ekspor Indonesia ke negaranegara ASEAN dan China selama 15 tahun dari tahun 2000 sampai dengan tahun 2014. Pengujian dilakukan dengan model data panel fixed effect dengan cross section SUR. Hasil penelitian ini menunjukkan bahwa ACFTA meningkatkan ekspor Indonesia ke negaranegara ASEAN dan China.
\end{abstract}

Kata Kunci: ACFTA; ekspor; liberalisasi perdagangan

First Draft: May 24, 2016; Revised: August 26, 2016; Approved: September 13, 2016 
The Effect of ASEAN-China Free Trade Area (ACFTA) on Indonesia Export Indriyani

\section{INTRODUCTION}

The process of globalization has led to the free trade accompanied by a form of cooperation bilateral trade agreements, regional and multilateral. ASEANChina Free Trade Area (ACFTA) is an agreement between the member countries of ASEAN and China to create a free trade area by removing tariff and non-tariff barriers. This agreement begins with the signing of the agreement on November 5 , 2002 in Phnom Penh. As one of the FTA, ACFTA accepted as forms of mutual benefit of the countries that binding agreements based on the concept of comparative advantage. A country will specialize in producing products that have a comparative advantage so as to create efficiency output of products can be further improved.

Figure 1 showed after the implementation of the ACFTA an increase of exports more than it was before the implementation of the ACFTA, Although Indonesia's exports to some countries are not so noticeable change in exports, namely to Brunei Darussalam and Laos. Before the implementation of ACFTA Singapore as export destination countries is in the first position compared to the ASEAN countries and China.

Prior to the implementation of the ACFTA, the United States ranks second as the main export destinations of Indonesia. After the implementation of ACFTA slowly position the United States as one of the main export destination countries shifted to China and Singapore. ASEAN countries certainly have a lot of potential to become an internasioanal trading partner of Indonesia because in one area. While China is currently the country with the second largest economy in the world, from 2000 to 2015, China's economic growth accounted for almost a third of global economic growth (IMF, 2016).

Paulino and Thirwall (2004) measure the performance of export competitiveness and the world's income, using panel data to determine the impact of liberalization on export growth, the data are estimated using estimator fixed effect and model of generalized methods of moments (GMM), the result of liberalization to encourage export growth but is lower than the rise in import growth, liberalization also negatively affect the balance of trade and payments. Park and Estrada (2008) found an overall ACFTA will increase net trade, output 
and regional welfare. However, the impact of each country is very diverse, the big advantage to countries like Singapore, Malaysia, Indonesia and Thailand compared to other countries that are relatively poorer members such as Cambodia, Laos and Myanmar. Another study also states trade liberalization have positive impact on export performance (Thomas, et al 1991; Bleaney, 1999; Wu and Zeng, 2008). However, there are also other researches that states liberalize trade only slightly greater impact on exports in the State to apply them (Lopez, 2005).

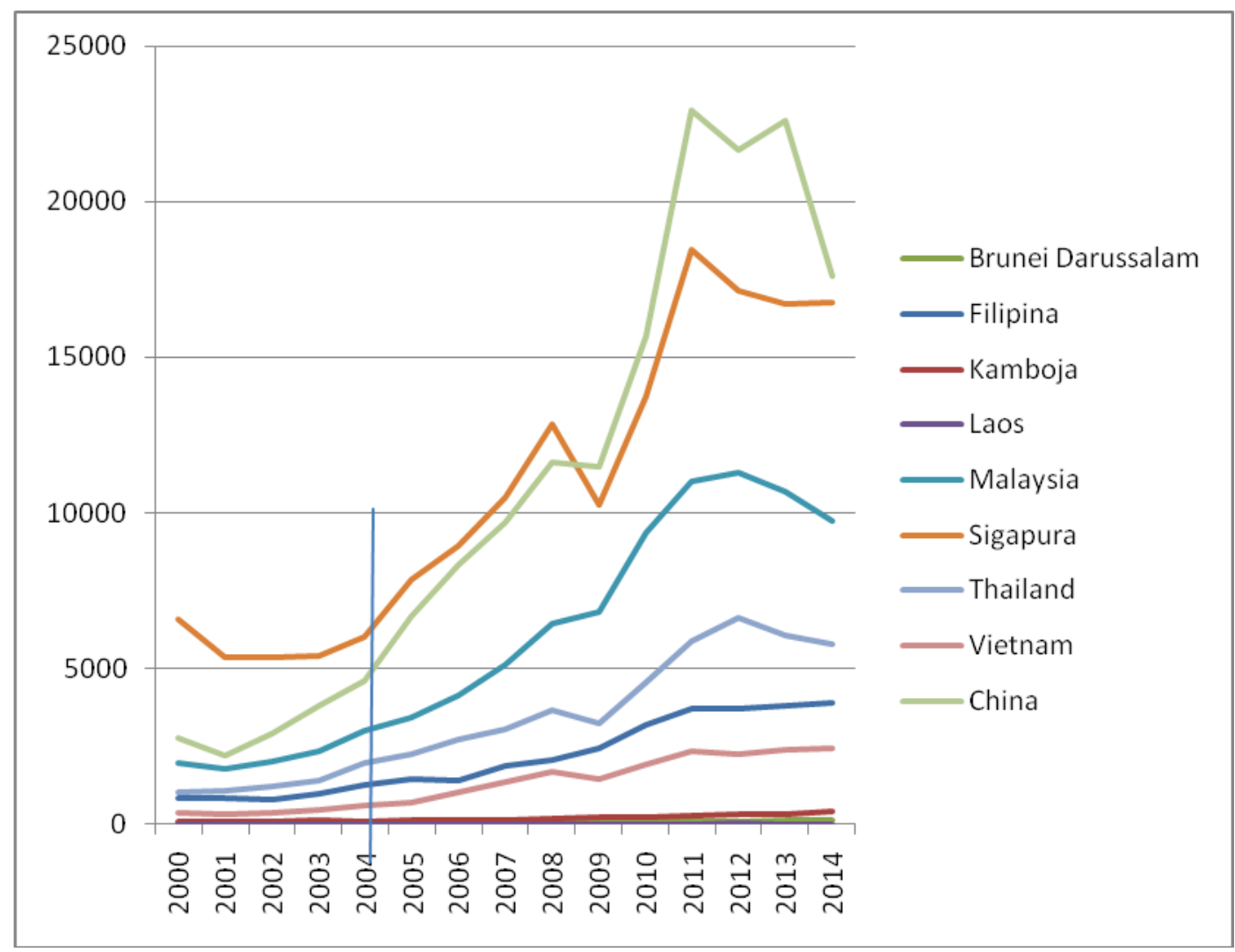

Figure 1. Export of Indonesia to ASEAN Countries and China 2000-2014

Source : $\underline{w w w . b p s . g o . i d}$ (data processed)

Several previous studies indicate that Indonesia has not been optimal in utilizing the ACFTA. Okamoto (2005) found in his research that Singapore and Malaysia gained the advantage of inter and intra-industry specialization, Thailand gain the advantage of intra-industry specialization, while Indonesia and the Philippines is not much gain from trade liberalization.Widyasanti (2010), which examined the impact of competitiveness Indonesia's exports after the 
implementation of ACFTA and AFTA wear HS (2 digits), in a study Widyasanti found before ACFTA commodity of forest products occupy the top 10 commodities for export to China but after ACFTA forest commodities not included again as a favorite commodity. Setiawan (2012) compared the export of Indonesia and China after the implementation of ACFTA, using time series data is the monthly export data in January 1990 - December 2011. Using the ARIMA econometric model where the variable Y ARIMA model described by the $\mathrm{Y}$ value it self at an earlier time.

The results of this study indicate Indonesia is not optimally utilized the ACFTA so as to obtain benefits that are less than the benefits of China, whereas in other studies, ACFTA provides opportunities for increasing exports of Indonesia, mainly from an increase in exports to China (Ibrahim, Permata and Wibowo, 2010). Ibrahim, Jewel, and Wibowo (2010) examined the impact of ACFTA on Indonesia exports using the GTAP model (General Trade Analysis Project) where it is assumed the world economy has been on a general balance.

Export data used in this study is Indonesia's exports to 113 countries. Simulation follows the closure standard GTAP namely: a variable price and quantity of a commodity that can be traded across countries and are not included in the category of endowment commodities placed as an endogenous variable, the income of each region is endogenous, the entire policy variables, productivity (technical changes) and the population was placed as a variable exogenous. The results of this study that ACFTA opportune to increase exports of Indonesia.

The purpose of the study is to determine the effect of the implementation of ACFTA on Indonesia's exports to the ASEAN countries and China. This study is expected to be one of the references of research associated with trade liberalization. Complementing previous studies on the effect of ACFTA for Indonesia where this study used an export demand model, price and revenue as control variables in this study. 
Table 1. The Previous Research About ACFTA

\begin{tabular}{|c|c|c|c|}
\hline Author & ear & Methode & Result \\
\hline Okamoto & 005 & $\begin{array}{l}\text { Revealed Comparative } \\
\text { Advantage (RCA) Index }\end{array}$ & $\begin{array}{l}\text { Singapore and Malaysia gained } \\
\text { the advantage of inter and intra- } \\
\text { industry specialization while } \\
\text { Thailand gain the advantage of } \\
\text { intra-industry specialization. } \\
\text { However, Indonesia and the } \\
\text { Philippines is not much gain. }\end{array}$ \\
\hline Park et al & 008 & $\begin{array}{l}\text { General Trade Analysis } \\
\text { Project (GTAP) }\end{array}$ & $\begin{array}{l}\text { ACFTA as a whole will increase } \\
\text { net trade, output and regional } \\
\text { welfare. The impact of each } \\
\text { country is very diverse, the big } \\
\text { advantage to countries like } \\
\text { Singapore, Malaysia, Indonesia, } \\
\text { and Thailand compared to other } \\
\text { countries that are relatively } \\
\text { poorer members such as } \\
\text { Cambodia, Laos and Myanmar. }\end{array}$ \\
\hline Widyasanti & 008 & Trade Indicator & $\begin{array}{l}\text { Before ACFTA commodity of } \\
\text { forest products occupy the top } \\
10 \text { commodities for export to } \\
\text { China but after ACFTA forest } \\
\text { commodities not included again } \\
\text { as a favorite commodity. }\end{array}$ \\
\hline $\begin{array}{l}\text { Ibrahim, } \\
\text { Permata, } \\
\text { dan Wibowo }\end{array}$ & 010 & $\begin{array}{l}\text { General Trade Analysis } \\
\text { Project (GTAP) }\end{array}$ & $\begin{array}{l}\text { ACFTA has the potential to } \\
\text { increase exports of Indonesia. }\end{array}$ \\
\hline Setiawan & 012 & ARIMA & $\begin{array}{l}\text { Indonesia has not been } \\
\text { optimally utilize the ACFTA so } \\
\text { as to obtain benefits that are } \\
\text { less than the benefits of China. }\end{array}$ \\
\hline
\end{tabular}

Trade between countries occur because of differences in relative prices. According to Krugman and Obstfeld (2003) the domestic demand for imports is an excess of what is required of consumers above that offered by domestic manufacturers, supply of foreign exports is an excess of what is offered by foreign manufacturers on requested by foreign consumers.

\section{METHOD}


The Effect of ASEAN-China Free Trade Area (ACFTA) on Indonesia Export Indriyani

This study uses regression analysis of data which is a combination of timeseries data and cross-section data called panel data. The empirical model in this study formed from the theory of demand for exports where exports are affected by income and price. While the model established equation is:

Export model:

$\operatorname{lnekspor}_{\mathrm{it}}=\mathrm{c}_{0}+\mathrm{c}_{1} \operatorname{lnhrg}_{\mathrm{it}}+\mathrm{c}_{2} \operatorname{lnpdbind}_{\mathrm{t}}+\mathrm{c}_{3} \operatorname{lnpdb}_{\mathrm{it}}+\mathrm{c}_{4}$ dummy ACFTA $\varepsilon_{\mathrm{it}}$ where:

lneksporit $\quad:$ log of Indonesia's export to country i year $t$.

$\operatorname{lnhrg}_{\text {it }} \quad: \log$ of Indonesia's export price to country i year $\mathrm{t}$

lnpdbind $_{\mathrm{t}} \quad$ : log of Indonesia's gross domestic product (GDP) year $\mathrm{t}$

$\operatorname{lnpdb} b_{\text {it }} \quad: \log$ of GDP of country i year $t$

dummy ACFTA $\quad$ after FTA $=1$

before FTA $=0$

Indonesia's exports to the ACFTA partner countries except Myanmar. There are 9 countries namely Brunei Darussalam, Philippines, Cambodia, Laos, Malaysia, Singapore, Thailand, Vietnam, and China. The value of exports used in this study is the real value of exports in the form of logarithms, i.e. nominal export value adjusted as the price deflator.

The data used in this research is data export from Indonesia to 9 partner countries ACFTA in 2000 until 2014. The export data obtained from UNCTAD-TRAINS (Trade Analysis and Information System) that are downloaded from the WITS (Word Integrated Trade Solution). Prices derived from the value of Indonesian exports to country i divided by the volume of Indonesian exports to country i. Data volume Indonesian exports to country i obtained from BPS (Badan Pusat Statistik). Real GDP of country i and real GDP of Indonesia from 2000 to 2014 was obtained from the World Bank.

Dummy variable in this study is intended to look at the effect of ACFTA policy implementation on Indonesia's exports to partner countries of ACFTA. Parameter estimation using panel data can be performed by three methods, namely Pooled Least Square method, fixed effect, and random effect method. In the Pooled Least Square (PLS) it is assumed that the individual effects did not vary between individuals are constant. In the fixed effect method characteristic differences between individuals in the model equations are accommodated in the intercept. If the individual effects correlated with one or more independent variables, the panel data model that can be used is the fixed effect model whereas if the individual effects are not correlated with each independent variable, the random effect models can be used. 
A series of tests are carried out to obtain the best panel data model. First, do a regression on the all panel data model, whether it is a model of pooled least squares, fixed effect and random effect. The second step is to test the Breusch-Pagan Lagrange Multiplier to select the best model among the pooled least square model with random effect model with the hypothesis $\mathrm{H}_{0}$ is pooled least square models and $\mathrm{H}_{1}$ is a random effect models and Hausman Test to choose which one is better between the fixed effect and random effect. Hypothesis used in this test is: $\mathrm{H}_{0}$ : Random effect $\mathrm{H}_{1}$ : Fixed Effect, if $\mathrm{F}_{\text {sta }}>\mathrm{F}_{\text {table }}$ or a $\mathrm{p}$-value $<\alpha$ then fixed effect better method for estimating panel data. The next step, performed classical assumption test. Multicolinearity test is by calculating the correlation coefficient between independent variables. If the correlation coefficient is below 0.8 , then there is no multicolinearity. Heteroscedasticity test assumptions used Breusch Pagan Godfrey, where $\mathrm{H}_{0}$ is homoskedasticity and hypothesis $\mathrm{H}_{1}$ is heteroscedasticity. In case of heteroscedasticity, then to obtain a constant residual variance estimator used WLS. Autocorrelation using BreuschGodfrey Serial Correlation LM Test where, $\mathrm{H}_{0}$ : non-autocorrelation and $\mathrm{H}_{1}$ : autocorrelation.

\section{DISCUSSION}

Selection of the best panel data model passed a series of tests. First, test all panel data model, pooled, fixed effect and random effect. The second step is Breusch Pagan LM test to select the best model among pooled with a random effect models and Hausman test to determine the most appropriate model among fixed effect model with random effect.

To choose pooled or random effect in this study using Breusch Pagan LM test, the hypothesis is a $\mathrm{H}_{0}$ pooled and $\mathrm{H}_{1}$ random effects models. Based on the test results the conclusion is known that reject $\mathrm{H}_{0}$. It can be seen from the P-value = $0.00<\alpha$, means the panel selected data model is random effect model. 
Table 2. Breusch Pagan LM Test Result

\begin{tabular}{lccc}
\hline $\begin{array}{c}\text { Null (no rand. effect) } \\
\text { Alternative }\end{array}$ & $\begin{array}{c}\text { Cross-section } \\
\text { One-sided }\end{array}$ & $\begin{array}{c}\text { Period } \\
\text { One-sided }\end{array}$ & Both \\
\hline Breusch-Pagan & 743.689 & 6.616 & 750.305 \\
& $(0.000)$ & $(0.01)$ & $(0.000)$ \\
\hline
\end{tabular}

Source: Data Processing Result

Furthermore, the election between the fixed effect model and random effect models with Hausman test, the hypothesis is $\mathrm{H}_{0}$ random effect models and $\mathrm{H}_{1}$ fixed effect model. After testing the Cross-section test variance is invalid. Hausman statistic set to zero. The test results show random effect models cannot be used. Ho refused meaning panel data model we have chosen is the fixed effect model.

The next step is after setting a fixed effect model as the best model to be used, then performed classical assumption. Multicolinearity test by calculating the correlation coefficient isamong independent variables. The test results showed multicolinearity not occur between the independent variable in which the value of the correlation coefficient $<0.8$.

Table 3. Multicolinearity Test Result

\begin{tabular}{ccccc}
\hline & LNHRG & LNPDBIND & LNPDB & DUMMYACFTA \\
\hline LNHRG & 1.000 & 0.101 & -0.609 & 0.106 \\
LNPDBIND & 0.101 & 1.000 & 0.124 & 0.750 \\
LNPDB & -0.609 & 0.124 & 1.000 & 0.099 \\
DUMMYACFTA & 0.106 & 0.750 & 0.099 & 1.000 \\
\hline
\end{tabular}

Source: Data Processing Result

To test the heteroscedasticityused Breusch Pagan Godfrey test, where $\mathrm{H}_{0}$ is homoscedasticity and hypothesis $\mathrm{H}_{1}$ is heteroscedasticity. Based on test results obtained Breusch Pagan Godfrey prob value obs ${ }^{*} \mathrm{R}$-square $<\alpha$ It follows reject $\mathrm{H}_{0}$, occurred heteroscedasticity. To solve the problem we can use Weighted Least Square.

Table 4. Heteroscedasticity Test Result

\begin{tabular}{lrll}
\hline Heteroskedasticity Test: Breusch-Pagan-Godfrey & \\
\hline F-statistic & 3.642 & Prob. F(4,130) & 0.008 \\
Obs*R-squared & 13.605 & Prob. Chi-Square(4) & 0.009 \\
Scaled explained SS & 7.938 & Prob. Chi-Square(4) & 0.094 \\
\hline
\end{tabular}




\section{Source: Data Processing Result}

To test autocorrelation using Breusch-Godfrey Serial Correlation LM test where, $\mathrm{H}_{0}$ : non-autocorrelation and $\mathrm{H}_{1}$ : autocorrelation. Based on the test results Breusch-Godfrey Serial Correlation LM Test prob value obs ${ }^{*} \mathrm{R}$-square $<\alpha$ so $\mathrm{H}_{0}$ rejected, meaning autocorrelation.

\section{Table5. Autocorrelation Test Result}

Breusch-Godfrey Serial Correlation LM Test:

\begin{tabular}{llll}
\hline F-statistic & 302.496 & Prob. F(2,128) & 0.000 \\
\hline Obs*R-squared & 111.425 & Prob. Chi-Square(2) & 0.000 \\
\hline
\end{tabular}

Source: Data Processing Result

From the classic assumption test results occurs heteroscedasticity and autocorrelation estimation can be done with a cross section-SUR fixed effect panel data model.After performing the specifications test, acquired the fixed effect model as the best model for estimating equation 1 with a cross section SUR. Based on estimates that have been made, adjusted R-square value of 0.997 indicates that the independent variables can explain the dependent variable of 99.7\%. F-statistics value of 3231.971 with prob (F-statistics) at 0.00 shows the independent variables jointly affect the dependent variable. From the results of the regression is known that the significant independent variables in the equation 3.1 are variable price (lnhrg), Indonesia's real GDP (lnpdbind), the real GDP of ASEAN countries and China (lnpdb), as well as dummy ACFTA (dummyacfta). It can be known from where the probability value is lower than the value of $\alpha$. The four independent variables significantly influence Indonesia's exports to the ASEAN countries and China.

Dummy variable (dummyacfta) in this study is intended to look at the effect of the implementation of the ACFTA on Indonesia's exports, using Indonesian exports to 9 countries, 8 ASEAN countries and China. Based on the results of the regression is known that the dummy variable ACFTA positive and significant with p-value $0.001<\alpha$. This result is consistent with the initial hypothesis that the ACFTA significant positive effect on Indonesia's exports to the ASEAN countries and China. ACFTA impact on Indonesia's exports to the ASEAN countries and China for 15 years amounted to 0.048 percent. 
Table 6. Fixed Effect Cross Section SUR Estimation Result

Dependent Variable: LNEKSPOR?

Method: Pooled EGLS (Cross-section SUR)

\begin{tabular}{|c|c|c|c|c|c|}
\hline \multicolumn{2}{|l|}{ Variable } & Coefficient & Std. Error & t-Statistic & Prob. \\
\hline \multicolumn{2}{|l|}{$\mathrm{C}$} & -12.083 & 0.687 & -17.578 & 0.000 \\
\hline \multicolumn{2}{|l|}{ LNHRG? } & -0.062 & 0.016 & -5.335 & 0.000 \\
\hline \multicolumn{2}{|l|}{ LNPDBIND? } & 1.221 & 0.088 & 13.932 & 0.000 \\
\hline \multicolumn{2}{|l|}{ LNPDB? } & 0.441 & 0.085 & 5.162 & 0.000 \\
\hline \multirow{2}{*}{\multicolumn{6}{|c|}{$\begin{array}{l}\text { DUMMYACFTA? } \\
\text { Fixed Effects (Cross) }\end{array}$}} \\
\hline & & & & & \\
\hline \multicolumn{6}{|c|}{$1-\mathrm{C}$} \\
\hline $2--C$ & & 0.206 & & & \\
\hline \multicolumn{2}{|l|}{$3--\mathrm{C}$} & -0.321 & & & \\
\hline \multicolumn{2}{|l|}{ _4--C } & -1.870 & & & \\
\hline \multicolumn{2}{|l|}{ _5--C } & 0.778 & & & \\
\hline \multicolumn{2}{|l|}{ _6--C } & 1.069 & & & \\
\hline \multicolumn{2}{|l|}{ _7--C } & 0.352 & & & \\
\hline \multicolumn{2}{|l|}{$8--\mathrm{C}$} & 0.361 & & & \\
\hline \multicolumn{2}{|l|}{ _9--C } & 0.283 & & & \\
\hline \multirow{2}{*}{\multicolumn{6}{|c|}{$\begin{array}{c}\text { Effects Specification } \\
\text { Cross-section fixed (dummy variables) }\end{array}$}} \\
\hline & & & & & \\
\hline \multicolumn{6}{|c|}{$\begin{array}{l}\text { Cross-section fixed (dummy variables) } \\
\text { Weighted Statistics }\end{array}$} \\
\hline R-squared & 0.997 & \multicolumn{2}{|c|}{ Mean dependent var } & \multicolumn{2}{|r|}{100.811} \\
\hline Adjusted R-squared & 0.997 & \multicolumn{2}{|c|}{ S.D. dependent var } & \multicolumn{2}{|r|}{98.205} \\
\hline S.E. of regression & 1.042 & \multicolumn{2}{|c|}{ Sum squared resid } & \\
\hline F-statistic & 3231.971 & \multirow{2}{*}{\multicolumn{2}{|c|}{ Durbin-Watson stat }} & \multicolumn{2}{|r|}{1.690} \\
\hline Prob(F-statistic) & 0.000 & & & & \\
\hline
\end{tabular}

Source: Data Processing Result

Indonesia's export prices are cheaper will stimulate an increase in exports of Indonesia. Conversely, the price of Indonesian export commodities will lead to increased domestic production less competitive against similar commodities produced by other countries. From the result of regression is that the price variable (lnhrg) significant negative effect on Indonesia's exports to the ASEAN countries and China with p-value $0.000<\alpha$. That is, if prices fall then Indonesia's exports to the ASEAN countries and China will increase. Price impact on Indonesian exports to the ASEAN countries and China for 15 years amounted to 0.062. That is, if the price rose 1 percent, the Indonesian exports to the ASEAN countries and China will decrease by 0.062 percent. 
Indonesia's Gross Domestic Product is the value of all goods and services produced within a certain time Indonesia. Where, in the event of an increase in the number of goods and services produced it will increase Indonesia's exports. The estimation results indicate that Indonesia's real GDP variable (lnpdbind) significant positive effect on Indonesia's exports to China with p-value $0.000<\alpha$. Indonesia's real GDP impact on Indonesian exports to the ASEAN countries and China for 15 years amounted to 1.221. That is, if real GDP rose by 1 percent Indonesia's exports to the ASEAN countries and China will increase 1.221 percent.

Gross Domestic Product ASEAN countries and China are all of the value of goods and services produced within a certain time. Where, in the event of an increase in real GDP of partner countries ACFTA will increase the purchasing power of the Indonesian export commodities. The estimation results indicate that real GDP variable ASEAN countries and China (lnpdb) significant positive effect on Indonesia's exports to the ASEAN countries and China with a p-value $0.000<\alpha$. The impact of real GDP of the ASEAN countries and China on Indonesian exports to the ASEAN countries and China for 15 years amounted to 0.441 . That is, if the real GDP of the ASEAN countries and China rose 1 percent, the Indonesian exports to the ASEAN countries and China will increase 0.441 percent.

\section{CONCLUSION}

ACFTA has a significant positive effect on Indonesia's exports to the ASEAN countries and China. ACFTA increase Indonesian exports to the ASEAN countries and China. In keeping with the liberalization of trade in which the ACFTA is one form of trade liberalization that the reduction and elimination of tariffs will increase exports.

Indonesia's export commodity prices significantly negative influence on Indonesian exports to the ASEAN countries and China. Rising commodity prices led to a decline of Indonesia's exports to the ASEAN countries and China. In accordance with the theory of demand, that rising prices reduce demand. Country trading partners will choose the lowest price of the alternative options for the 
same commodity. That is, the lower price increased competitiveness, if competitor countries offer the same commodity at a higher price.

Indonesia's real GDP has a significant positive effect on Indonesia's exports to the ASEAN countries and China. If real GDP increases, Indonesia's exports to the ASEAN countries and China will increase. Indonesia's real GDP is the value of goods and services produced in Indonesia within a certain time-adjusted price. Indonesia's real GDP increased demonstrate Indonesia's ability to produce export commodities also increased.

Real GDP of the ASEAN countries and China have a significant positive effect on Indonesia's exports to the ASEAN countries and China. Increased revenue partner countries ACFTA will increase the purchasing power of the Indonesian export commodities. This is consistent with the theory demands that the increase in income will increase the demand for normal goods.

This study looked at the impact of ACFTA on Indonesia's international trade from the export side without looking at the impact on Indonesia's imports. This is one of the limitations of this study and further research can do a comparison of ACFTA impact on exports and imports.

The increase in real GDP of partner countries ACFTA impact on Indonesian exports, according to the theory of demand that rising incomes will boost demand for commodities is assuming normal goods. However, Indonesia could not regulate the rise and fall of the purchasing power of other countries. The government needs to focus on improving the competitiveness of Indonesia's export commodities so that prices can be bought at a cheaper price compared to the same commodity from other countries. Indonesia's real GDP is the independent variable that also has a significant effect. There should be efforts to continuously increase real GDP Indonesia. ACFTA increase Indonesian exports to the ASEAN countries and China is consistent with the theory that the liberalization will boost exports. The research looked at Indonesia's exports to the ASEAN countries and China as a whole. It would be interesting if further research can demonstrate the impact of ACFTA in each sector. 


\section{REFERENCES}

Appleyard, D.R.et.al. (2010). International Economics. Singapore: Mc Graw Hill.

Bleaney, M. (1999). Trade Reform, Macroeconomic Performance and Export Growth in Ten Latin American Countries 1979-1995. Journal of International Trade and Economic Development,. Vol. 8: 89-105.

Heng \& Gayathri. (2004). Impact of Regional Trade Liberalization on Emerging Economies: The Case of Vietnam. ASEAN Economic Bulletin. Vol. 21 (2): 167-182.

IMF. (2016). Asia and Pacific Building on Asia's Strengths during Turbulent Times. World Economic Financial Surveys: Regional Economic Outlook Asia and Pacific, April 2016.

Kalirajan, K. (2007). Regional Cooperation and Bilateral Trade Flows: an Empirical Measurement of Resistance. The International Trade Journal.Vol. 21(2): 85-107.

Kreinin \& Plummer. (1994). Economic Effects of the North American FreeTradeArea on Australia and New Zealand.Journal of Economic Integration. Vol. 9, No. 1: 1-28.

Krugman, P\& M. Obstenfeld. (2003). Internasional Economic: Theory and Policy. United States: Pearson Education.

Kusi, N.K. (2002). Trade Liberalization and South Africa's Export Performance. Trade and Industrial Policy Strategies. Annual Forum. Muldersdrift.

Lopez, P. (2005). The Effect of Trade Liberalization on Export, Import, The Balance of Trade, and Growth The Case of Mexico. Journal of Post Keynesian Economies. Vol.27, No.4: 595-619.

Okamoto, Y.(2005).China and India: Challenges and Opportunities for ASEAN from Japanese Perspectives. Doshisha University. Japan.

Park, D. et.al. (2008). Prospects of an ASEAN-People's Republic of China Free Trade Area: A Qualitative and Quantitative Analysis.ADB Economic Working Paper Series, No. 130. Asia Development Bank. 
The Effect of ASEAN-China Free Trade Area (ACFTA) on Indonesia Export Indriyani

Santos-Paulino, A.\&A.P. Thirlwall. (2004). The Impact of Trade Liberalisation on Exports, Imports and The Balance of Payments Of Developing Countries. The Economic Journal.Vol. 114: 50-72.

Setiawan, S.(2012). ASEAN-China FTA: The Impacts on The Exports of Indonesia and China. Pusat Kebijakan Regional dan Bilateral, Badan Kebijakan Fiskal Kementerian Keuangan-RI.

Thomas, V. et.al. (1991). Best Practices in Trade Policy Reform. Oxford: Oxford University Press for The World Bank.

Widyasanti, A.A. (2010). Do Regional Trade Areas Improve Export Competitiveness? - A Case of Indonesia. Bulletin of Monetary, Economics and Banking, July 2010.

Wu,Y.Z.L. (2008). The Impact of Trade Liberalization on The Trade Balance in Developing Countries. IMF Working Paper. 